Dr Mariadele Boccardi

Senior Lecturer in English

Department of Arts and Cultural Industries

University of the West of England

St Matthias Campus

Fishponds, Bristol

BS16 2JP

01173284457

Mariadele.Boccardi@uwe.ac.uk

Mariadele Boccardi is the author of The Contemporary British Historical Novel (Palgrave 2009) and A.S. Byatt: New British Fiction (Palgrave 2013). Contemporary historical fiction is her long-standing research specialism and she has published widely on the subject. Her current research considers the use of natural history in Neo-Victorian novels through the lens of post-colonial theory and eco-criticism. 


\title{
The naturalist in the Garden of Eden: Science and colonial landscape in Jem Poster's
} Rifling Paradise (2006)

Mariadele Boccardi (University of the West of England)

\begin{abstract}
This essay seeks to supplement an established critical tradition that reads natural history in Neo-Victorian fiction from a post-modern and largely de-politicised perspective. I argue that the figure of the naturalist can be used to revisit natural history's complicity with imperial expansion, both in its practice and in its discursive framework. By means of a close reading of Jem Poster's Rifling Paradise (2006), I explore the ways in which natural history gives way to an ecological approach to the colonial landscape, pointing to a possible - though still problematic - alternative to a scientific (exploitative, colonial) understanding of the relationship between nature and human beings.
\end{abstract}

Keywords: Eco-criticism; ecology; natural history; colonial landscape; pastoral; wilderness; Neo-Victorian fiction; colonial discourse

\section{Natural history and Neo-Victorian fiction: the critical tradition}

In what has since become a defining contribution to the study of neo-Victorian fiction's appropriation and reshaping of nineteenth-century discourses, Sally Shuttleworth (1998) first noted contemporary historical novels' persistent deployment of natural history as an element of the plot (where encounters with fossils are opportunities for set-piece confrontations between representatives of science and religion); as an implicit structuring device which casts the relationship between the Victorian past and its Neo-Victorian descendant in evolutionary terms; and most significantly as a form of nostalgia for a perceived 'intensity of emotion and 
authenticity of experience' of the Victorian crisis of faith, which appears desirable in 'a postmodern era [where] no such form of crisis seems possible, for there are no fixed boundaries of belief' (Shuttleworth 260; original emphasis).

Shuttleworth's broadly postmodern approach to Neo-Victorian novels' use of natural history has been influential. A.S. Byatt, herself a foremost practitioner of the contemporary historical novel and an often perceptive reader of it, suggests that contemporary historical fiction's interest in "forms of fiction of the ideas we loosely call "Darwinian"" is the result of a shift in 'the large paradigmatic narratives that we inhabit' (65). In this view, Victorian natural history, with its emphasis on chance and randomness, is consistent with a present-day reluctance to allow for historical or providential agency in human lives. As was the case with Shuttleworth, the Victorian perspective is both privileged for providing an effective frame to understand the present and attenuated, in that the frame only serves to draw attention to the proper subject of discussion, namely, the post-modern sensibility.

More recently, in separate chapters appearing in the same volume, Georges Letissier and Catherine Pesso-Miquel (2010) have read Neo-Victorian fiction's deployment of recurring natural history tropes within the frame of trauma theory. In an argument that differs only slightly from Shuttleworth's, they suggest that the crisis-of-faith narrative enables NeoVictorian authors to re-live a real historical trauma impossible to replicate in the present, which, because of that impossibility, is somehow desirable. Once again, authenticity - and its perceived contemporary loss - is central, as the volume's editors make clear in their reference to an 'epistemological component' to the Neo-Victorian 'ubiquitous sense of trauma' (Kohlke and Gutleben 4).

What these positions have in common is, firstly, the unquestioned acceptance of an exclusively theoretical dimension to natural history, whereby geology, evolutionary biology 
and cognate disciplines (such as botany, zoology, ethnography) are not examined in their practice but only for their conceptual helpfulness to the present time's understanding of itself; secondly, an implied privileging of the Victorian experience over its contemporary counterpart, on the grounds of the former's authenticity, substance, originality, innocence, which contrast favourably with the latter's inauthenticity, superficiality, derivativeness, knowingness. Most damning is the seeming blindness to the implications of the perspective outlined above, namely, that in its practice natural history was inextricably involved in the construction of colonial territories as ripe for exploitation and that the very attributes of the Victorian experience deemed so desirable by contemporary novelists (and critics) are in fact those deployed to obfuscate the reality of imperial expansion.

\section{The imperial connotations of natural history}

As William Beinart and Lottie Hughes (2007) suggest, European naturalists, 'who combined touring with botany and other scientific, or quasi-scientific, enquiries [...] did more than most to promote the natural potential of empire' (77). Indeed, as 'an expression of the will to control, categorize, occupy, and bring home the prize of samples $[\ldots][n]$ atural history and national future were easily interlocked' (Beer 59). However, the seeming scientific disinterestedness of the naturalists was crucial to preserving their innocence from the violence inherent in the exploitation of imperial lands (and peoples) which their very work, with its description of teeming and apparently empty space, had encouraged. To this end, the emphasis was on the descriptive means and aims of natural history (Pratt 33).

It is in the texts engendered by the enterprise of natural history in colonial outposts that the rejection of complicity in the colonial project on the part of its practitioners is most obviously articulated: alongside the predictable 'Europeanness, maleness, and middleclassness' of the naturalists' portrayal of themselves are the less expected characteristics of 
'innocence and passivity' (Pratt 78). These are, in turn, validated by the two-pronged authenticity of originary experience and subsequent textual account, provided by '[d]iaries, field notes, samples, and specimens [...] vouching for the objectivity of the record', on the one hand, and by 'the personal moment, the record of what is smelt, touched, tasted, seen and heard by the subject' (Beer 56) on the other. Thus, a setting along the Jurassic coast may provide, for authors and critics alike, a convenient opportunity for pleasing intertextuality and alternatively playful or traumatic recognition of contemporary inauthenticity. In a colonial context, on the other hand, intertextuality is a means to imposing Western categories onto a recalcitrant territory, whose authenticity is either unacknowledged (being replaced with the naturalist's authentic experience) or enshrined (once its destruction guarantees that it no longer threatens to usurp that experience) in natural history collections and museums.

\section{Natural history and empire in Neo-Victorian novels}

There is now a substantial body of Neo-Victorian novels that show awareness of the practical, historical and discursive intersections of natural history and colonial enterprise. Some, like Roger McDonald's Mr Darwin's Shooter (1998), Nicholas Drayson's Confessing a Murder (2002) and Harry Thompson's This Thing of Darkness (2005) return to the life of the founder of evolutionary biology, in order to place his actions under scrutiny for their impact on those surrounding him (including colonial subjects). These texts place Darwinian science under an ethical spotlight. Other novels, including Matthew Kneale's English Passengers (2000) and Rachael King's The Sound of Butterflies (2006), centre on natural history's ostensibly benign and disinterested activities, which are in fact revealed to be no more than the palatable arm of oppression. Finally, Jem Poster's Rifling Paradise (2006) supplements a similar piercing of the discourse of natural history with an ecological solution to the problem of the relationship between the imperial subject and the colonised territory. 
The novel's approach is consistent with Elizabeth Ho's description of Neo-Victorianism as a site 'for confronting empire again and anew', so that 'the memory of empire and its surrounding discourses and strategies of representation can be replayed and played out' (5). Thus, Poster variously draws on the discourses of natural history, imperial masculinity, and the pastoral in order to show their inadequacy and challenge their validity. Yet, as I will argue in this essay, this critique of nineteenth-century discourses risks resulting in dubious solutions, which ultimately do little more than replace one set of now unacceptable Eurocentric, hegemonic assumptions with a more palatable but no less insidious one.

Set in Australia at the end of the nineteenth century, Rifling Paradise explores natural history's complicity with the enterprise of empire by probing the long-standing legacy of the former's inherently anthropocentric and non-reciprocal (Pratt 81) discourse of nature. Poster constructs a plot where nature ultimately others the colonial intruders, first revealing and then defeating their exploitative purpose. The novel's narrative moves towards a recognition that the foundational premises and actual practices of natural history ought to be discarded in favour of an ecological understanding of the colonial landscape.

At the centre of Poster's novel - its homodiegetic narrator and amateur naturalist - is Charles Redbourne, owner of a small and neglected estate in England, who is forced to leave the country after the suicide of a young labourer towards whom he had shown improper interest and of whom he had taken inappropriate photographs. Redbourne's characterisation early in the novel reads like a compendium of attributes of the Victorian naturalist. Needing to flee his home, he turns to his childhood passion for a form of natural history modelled on adventure stories: his imagination is caught up in 'the exploits of those naturalists who, with scant regard for their own personal comfort and safety, had obstinately pursued their quarry their specimens, their theories - to the most remote corners of the earth' (17). The phrasing 
suggests that Redbourne has read the kind of nature writing (in the first person, by a Western experiencing subject unflinchingly dedicated to his scientific mission and guarantor of the authenticity of the text that is the outcome of that mission) identified by Mary-Louise Pratt as projecting 'a utopian image of a European bourgeois subject simultaneously innocent and imperial, asserting a harmless hegemonic vision that installs no apparatus of domination' (334). However, Redbourne's reference to the naturalists' obstinacy suggests a degree of selfcentredness that differs from unselfish scientific pursuit, while the hastily qualified 'quarry', whose first association for a late-Victorian landowner must be to blood-sport, points to the colonial violence the natural history text suppresses. Clearly, this is a Neo-Victorian novel probing the nineteenth-century discourse of natural history.

A similar tension between selfishness and scientific altruism is evident in Redbourne's acknowledged aims of his journey: 'I should add significantly to my collection and I should contribute my quota to the sum of human knowledge' (19). The possessive adjective precedes both the practical outcome of the expedition (the collection) and its more intangible abstract counterpart (human knowledge). There is comparable ambivalence of allegiance in the description of his preparation for the enterprise: the practical accoutrements of the naturalist 'nets and collecting-boxes' (19) - are accompanied by the suggestion of a textual dimension to the expedition, as Redbourne takes 'books and papers' (19), while what must be left behind (the compromising pictures) is burned in 'an act of propitiation, a sop to Daniel's aggrieved and possibly vengeful spirit' (26). The presumed scientific framework for the journey is progressively destabilised firstly by the acknowledgement of its concomitantly material and textual outcomes and secondly by the proleptic voicing of an aboriginal animist discourse which will be fulfilled in the Australian outback. 
Initially, however, and in a fashion consistent with Eurocentric colonial discourse, Redbourne envisages Australia as no more than a useful catalyst for personal fulfilment: 'Australia was to be the crucible in which I should be made new. My arrival there was an event of extraordinary personal significance [...] after years of inertia' (52). Not only is the refashioning of the white man - aided by the deployment of scientific implements that function as 'props' (Scholz and Dropmann 173) - the aim on which the entire enterprise is predicated; the suggestion that the refashioning consists of a change from 'years of inertia' evokes the late-Victorian scientific, cultural and social discourse of degeneration, whereby the colonies offered an arena to rediscover a (white) masculinity that had been undermined by the excesses and indulgences of advanced civilisation at home. This same discourse underscores the popularity of the colonial adventure romance, the genre modelled on the kind of writings by naturalists operating at the outposts of empire which Redbourne cites as early influences. Redbourne thus expects to be 'cured' of his form of degeneracy - which predictably manifests itself in homosexual desires - by first-hand encounters with the 'uncorrupted' colonial surroundings.

The premise for Poster's narrative of Redbourne's adventures in 'uncivilised' territory is therefore firmly located in the intersection between science (the understanding that evolution could reverse into degeneration under particular conditions (see Robbins 2006, 12858)); a colonial reality that required a sense of masculinity constructed around violence; and the literary-critical dissatisfaction with a perceived feminisation of the novel, as evidenced in Andrew Lang's well-known essay 'Realism and Romance' (1887). Lang suggests that the masculine romance provides proper release for a masculinity whose inherent savagery is repressed in the civilised metropolitan centre. Similarly, public intellectuals 'warned [...] against the corrupting effeteness and frivolousness of contemporary life in England, and 
advocated instead manly activities abroad' (White 43). If 'the vitality of the race could be renewed at the colonial frontier' (Dixon 3), conveniently primed for settlement by narratives of natural exploration, preparation for this encounter with colonial territories was provided by the adolescent adventure stories set in imperial territories. These helped establish the 'heroic cultural status of the Victorian explorer' (Woollacott 59), superimposing imaginary adventures onto a real landscape validated by natural history texts. Charles Redbourne in Rifling Paradise, a former reader of masculine romance but now idle, prematurely aged, and attracted to men of lower social class, is the ideal test case for the claims of regeneration made on behalf of colonial exploration.

\section{Empire and pastoral.}

The casting of the colonial territory as the repository of attributes of wholesomeness lost by the unnatural metropolitan centre is consistent with a pastoral understanding of the empire which, as Pratt argues, shapes the narratives of natural history expeditions to colonial territories into paradoxical texts, telling 'a story of urbanizing, industrializing Europeans fanning out in search of non-exploitive relations to nature, even as they were destroying such relations in their own centers of power' (28). Consequently, the 'various "exotic" settings' of adventure fiction 'celebrated [...] a pre-industrial past, and particularly after mid-century the nostalgia implicit in this fiction fulfilled the industrialized reader's desires for Edenic, unspoiled beauty' (White 63). The pastoral's dichotomies of town and country, past and present are re-cast in the imperial reality by expanding their geographical scope and substituting it for a temporal one: so, the metropolitan centre of England stands to its colonial outposts as the city to the country in the classic pastoral; in addition, the premise of colonial discourse, whereby the colonial territories embody an earlier state of civilization, functions positively to make the pastoral tendencies actual rather than just literary (nowhere more so 
than in Australia, where literal pastoralism was at the basis of early economic development of the country). Indeed, because of its geographical connotations the colonial pastoral participates of all three 'orientations' of the genre identified by Greg Garrard (2012: 42). The elegiac 'looks back to a vanished past with a sense of nostalgia' (42) and properly belongs to the advanced imperial metropolis, but once displaced onto colonial lands it turns into the idyllic incarnation of pastoral, which 'celebrates a bountiful present' (42) and, in the seemingly illimitable scope offered by the vastness of the colonial territories, becomes the utopian realisation of 'a redeemed future' (42).

Predictably, Redbourne's perspective on his arrival in Australia articulates a metropolitan pastoral view. Discussing his forthcoming trip into the outback at the table of his host, Mr Vane, with Vane's daughter Eleanor and his own paid guide Mr Bullen, Redbourne is dismayed to hear that he will undertake the journey partly by train. He reflects on 'how the face of England has changed since my childhood - the railways reaching into all those quiet corners, the cities spreading outward like dirty stains' in contrast to '[o]ut here, with so much splendid scenery still unspoiled -' (121). Vane, however, seizes on this comment to put forward a view of inexhaustible nature so abundant 'that our own petty activities - railway construction, tree clearance, mining - make scarcely any impression' (121). The 'sheer immensity of the land' promises a version of cornucopia - of 'resources we've scarcely begun to draw upon' (121). The pronoun and active form of the verb, however, suggest that the land is not giving up its bounty willingly but as a result of men's work, which in turn relies on the scientific knowledge (not least of plants and rocks) obtained by means of natural history and on the technological advances made possible by industrialisation. The metropolitan pastoral dream, innocuous because unrealisable, becomes something closer to a practical 'science of nature' when voiced in a land where its enactment is possible. Not only, then, is the pastoral 
an imperial import dependent on 'a perspective that saw land to be cultivated, improved, planted' so as to confirm a pre-existing 'European cultural discourse' (Hooper 5); in order to be made reality on a territory that does not naturally conform to its parameters, the pastoral paradoxically relies on modern science such as the knowledge of local flora and fauna, sources of irrigation and pollination, pests and resistance to them, provided by ecology (Griffiths 2-3).

Redbourne's pastoral ideals are a product of an advanced industrial society, whose imagined elegiac past is one of nature already tamed by agriculture and made to yield its wealth to those who work it. In settler Owen Preece's small patch of land, he sees that vision realised: '[v]ines ran riot over a rough trellis, their arching stems festooned with clusters of small purplish grapes, while further down I could see staked rows of beans, the brighter greens of assorted leaf-crops and the gleam of melons and pumpkins lying in the shadow of their own broad leaves' (166). The seeming spontaneity of the vines' growth is balanced by the deliberately contained beans. Redbourne refers to this orderly abundance as 'a veritable paradise', but Preece's explanation of his achievement belies the Biblical phrase: the 'fertile garden' is maintained by '[h]alf a dozen cartloads of dung each winter and bucket after bucket of water raised from the gully throughout the summer' (166). By itself, the land offers neither natural fertility nor spontaneous irrigation. As Redbourne will discover in the course of the novel, the outback is, more properly, a wilderness that resists accommodation within the parameters of the pastoral.

Ultimately, both Redbourne's and Vane's respective attitudes are versions of an anthropocentric understanding of nature, whose importance is subsumed to either nostalgia or progress: both inherently human perspectives. Eleanor Vane, on the other hand, puts forward an alternative relationship between human beings and nature, which consists of 'knowing 
when we should stop trying to set our stamp on everything we see - knowing when to stand back and admire the world instead of forcing ourselves on it' (123). Her dissenting voice pierces the orthodox justification of specimen collecting (with the concomitant violence suppressed in the tame phrase) as 'a repository of facts from which important scientific truths may be deduced, and new theories constructed' (67). Instead, she characterises collecting as essentially sterile, emphasising the distance between '[w]hatever it is you imagine you're laying hold of' and the reality of it, which is 'gone the moment you pull the trigger' (68).

From her un-ladylike appearance to her forthright opinions, from her kinship with the creatures Redbourne collects to her vision of her mother's ghost, Eleanor's strangeness is a prelude to the otherness of the outback, particularly in her undermining of the imperial masculinity Redbourne fashions for himself as the scientist-explorer-collector. The outback, at the centre of the country and in the middle of the novel and therefore presented as the real or true Australia, will complete Redbourne's unmanning. However, at this early stage in the novel Eleanor shows up the constructed nature of that masculinity, which relies on a gendered understanding of the relationship between colonial naturalist (armed with phallic rifle) and colonised territory (ready to be plundered for its beauties). Eleanor then functions in the novel as something close to an allegory of the country, not least in the incestuous sexual violence which her father has perpetrated on her for years. The relationship based on taking by force what she cannot help giving up, albeit unwillingly, stands as an effective counterpart to the non-reciprocal exchange of colonialism. The self-declared (male) protector imposes himself on a (feminised) territory, ownership and guardianship of which he holds by law. However, the shocking impropriety of Vane's treatment of his daughter implies a comment on the similarly unequal and inequitable dynamics of colonisation. 
The novel's suggestion of allegory does not include an aboriginal presence or experience: it rests for its meaning on a relationship between white people on an estate broadly modelled on an English country house. The paradox of a colonial land violently othered by being made to conform to a pre-existing vision from the metropolitan centre finds confirmation in the incest: in Vane's confused understanding, Eleanor's uncanny resemblance to her dead (English) mother is a central cause of his actions. Australia is envisaged as already fallen by virtue of being conceived as a paradise, a Western concept whose application to the antipodes cannot make theological sense of the pre-existing inhabitants (and therefore leaves them out of its narrative). With typical prescience, Eleanor puts this into words in a discussion of Milton's description of the Garden of Eden in Paradise Lost (1674): 'Satan. We've waited for our glimpse of paradise, and here it is at last, but he's there with us. [...] I want to see the garden pure and clear, and I can't. Milton won't let us' (94). The purity and clarity she desires are unavailable to the white settlers because their very presence marks the undoing of paradise.

This insight is confirmed when Redbourne and Bullen venture into the outback. The nature they encounter defies both scientific and sentimental approaches to it, retaining its otherness with respect to human experience and human categories of classification. Thus, Redbourne remarks, the landscape is marked by 'a blank imperviousness to our presence' so that 'nothing seemed intended for my eyes, or for those of any intruder in that heartless, unblemished wilderness' (101). The taxonomic and epistemological power of natural history is voided by Redbourne's realisation that he 'had no name' (188) for many of the plants he is observing. He therefore resorts to recasting his situation in Biblical or Miltonian terms, with himself in Adam's place - but an Adam aware that his 'fall might have begun not with the eating of a fruit but earlier, with the arising of the desire to catalogue the animals and plants in 
his teeming paradise' (188). Finally, he acknowledges that his approach to the expedition (and to nature more generally) is over-determined by his cultural affiliations, whether they be literary works like Paradise Lost or scientific texts; Redbourne can then discard the anthropocentric expectation that venturing deeper into the wilderness will 'bring us progressively closer to some teeming source or centre of life' (212). Instead - and in appropriate ecological fashion - the landscape, its nature, the place itself remain unknowable.

What the explorers are faced with instead is a materialisation of the desires and fears they have carried with them into the outback. Bullen's sense of inferiority because of his low birth crystallises in his vision of an as yet undiscovered bird, which will grant him fame and recognition in the scientific community. His frustration at failing to shoot the specimen turns into antipathy for the mixed-race Billy Preece, whom they have hired as a guide and whose knowledge of the wilderness is presented as genetic (inherited from his aboriginal mother) rather than learnt. Billy's communion with the land allows him to find suitable shelter and sources of water, while his uncanny awareness of his ancestors' presence in that landscape leads him to warn Bullen and Redbourne against camping in particular spots or indeed shooting the mysterious bird. This unscientific apprehension threatens to usurp the others' presumed knowledge and is thus predictably dismissed in the name of reason and science. However, when Billy disappears and the explorers are left to fend for themselves in a landscape they cannot assimilate to familiar categories his claims are vindicated: Bullen falls ill of a (possibly supernatural) fever and dies, while Redbourne is visited firstly by the (possibly feverish) vengeful spirit of the young labourer whose death he had sought to escape by journeying to Australia and then by a vision of Eleanor as temptress and redeemer at once.

The experience is terrifying because it transcends what Redbourne's Western, scientific mind can encompass; the resulting insight (and the only explicitly retrospective statement in 
the novel) is that 'we live in a world that cares nothing for reason' (234). No longer able to 'pla[y] the role of one of the heroes of my childhood reading, battling gamely against a dangerous but ultimately tameable universe' (249), Redbourne admits to his actual situation, 'weak and giddy, lost in that vast wilderness' (249). If the naturalist cannot rely on reasonthe discriminating value of Western colonial discourse, against which other cultures were measured and found wanting - he must adopt (wittingly or otherwise) aboriginal behaviours. So, in order to make his way back to Preece's cabin, Redbourne leaves behind all the tools and trappings of the naturalist-explorer, the specimens collected and the dead Bullen, setting fire to them in what is both a sacrificial offering akin to the burning of the photographs before he sailed for Australia and a repetition of native practices (burning the bush to hasten its regrowth and to aid hunting) which Eleanor explains to him once he returns to the Vanes. The action manages to connect Redbourne with his past in England and the aboriginal past of Australia, even if the latter still eludes his apprehension or understanding because it is so closely tied up with the natural world whose scientific pursuit he has forfeited.

The central section of Rifling Paradise dismantles the material and textual apparatus of natural history (from exploring to collecting - code for conquest and killing respectively) by foregrounding its conceptual and practical limitations. The former reside on the preconceived understanding of a relationship between (Western) man and nature that cannot apprehend the reality of the colonial environment on its own terms; the latter rests on the naturalist's inability to make use of science in the alien landscape of the outback. Poster's suggestion is ecological in a modern (rather than a scientific) sense: it acknowledges nature's resistance to exploitation and places nature's needs on a par with those of human beings.

\section{Ecology and empire.}


Lawrence Buell (1995) proposes four criteria to determine whether a text's treatment of nature transcends the ideological limitations of the pastoral and can properly be called ecological:

1. The nonhuman environment is present not merely as a framing device but as a presence that begins to suggest that human history is implicated in natural history;

2. The human interest is not understood to be the only legitimate interest;

3. Human accountability to the environment is part of the text's ethical orientation;

4. Some sense of the environment as a process rather than a constant or given is at least implicit in the text. (7-8)

Rifling Paradise satisfies all of these. Not only is the Australian landscape a determining factor in the events of the novel (and not just background to them), the outback emerges as a space to which attention, consideration and respect are due because it is inimical to human habitation. Eleanor's ecological understanding of nature voices the novel's ethical stance and, in its suggestion of nature's independence from human intervention, implies that the former exists - and undergoes changes - regardless of any human witness to them. Poster clearly and explicitly proposes an ecological attitude to the colonial landscape as a viable and preferred alternative to the scientifically-inflected imperial exploitation of resources.

Ecology, however, in its origins as a science of nature ('the study of organisms in relation to each other and to the surroundings in which they live' (Clark 152)), is itself imbricated with imperial concerns, particularly in Australia, the 'paradise' in Poster's title - a term whose inappropriateness, as I have argued, is discursive as much as substantive, in that the very notion of paradise carries with it a Western, colonising attitude to nature. Libby Robin (1997) points to the fact that 'Australian ecology emerged from a background of "empire science"” which included 'natural history, especially taxonomy and systematics' (64). 
Its practice participates of an imperial discourse of economic development, which 'deals with the ecological limits of empire: the difficulty of establishing European agriculture, pastoralism, and other "improvements" within pre-existing non-European ecosystems [...] dependent on indigenous management techniques' (Robin 63). Bullen, a foil to Redbourne's understanding of Australia, voices this utilitarian aspect of imperial ecology, which consists of 'taking Nature in hand and letting her know we mean business' (121). Even Preece, for all his moral attractiveness, relies on agricultural knowledge derived from imperial science to perpetuate the apparent paradise in his corner of tamed nature.

Bullen functions as a useful corrective to Redbourne's alternatively naïve and sentimental attitudes to his presence and activities in Australia. In particular, because he is not a gentleman-amateur and instead requires to be paid for his services, he undermines the ostensible disinterestedness of natural history in a colonial setting. Early in the novel Vane describes Bullen as not 'what you'd call [...] a naturalist' nor 'by any stretch of the imagination, a scientist' (57). Shorn of the attributes granted by the discourse of natural history the true aims of his activities (and by implications those of scientists more broadly, since they differ from Bullen only in their title) are revealed. Bullen wants 'to discover a new species of bird or mammal [which] they'll name after him' (57); he envisages the settlers' penetration into the interior as 'a war, an unending battle with a heartless enemy', namely, 'the wilderness' (186); he chides Redbourne for his 'sentimentalism', which he defines as an anti-scientific attitude ('Looking for mysteries when the facts are staring us in the face' (78)), reminding him that birds of prey don't 'share your finer feelings' (78); and he deploys the knowledge derived from natural history to justify an uncomfortable level of violence to the creatures he collects: 'Science tells us' that 'these creatures don't suffer the way you or I do' (103). 
Most importantly, Bullen's presence and mediating intervention in Redbourne's first encounter with aboriginals both allow the naturalist to perpetuate the fiction of a disinterestedly scientific attitude to colonisation and expose it as untenable. At the edge of the outback, in what is a textbook example of contact-zone transaction, Redbourne spots a bracelet being worn by an aboriginal girl and wonders whether 'they [will] let us have that' (155). The phrasing conveniently implies the choice and selflessness of gift-giving, but, in the face of Bullen's incredulity, Redbourne corrects himself and suggests 'trad[ing] the bracelet' (155). The altruism has become commerce, as such more in line with the colonial realities of the contact-zone. Bullen, now in his element, ever practical and unimpeded by the anticonquest posturing gripping his companion ('whereby European bourgeois subjects seek to secure their innocence in the same moment as they assert European hegemony’ (Pratt 7)), flatly declares the bracelet '[c]ompletely worthless' (156). But Redbourne reacts to this statement of the truth by replacing monetary worth with 'cultural value' (156), thus diminishing the suggestion that what he is engaged in is anything like a routine (and routinely unequal) colonial exchange. Once started, the conventions of the trade do not allow Redbourne to withdraw from it, even though he realises that the girl 'doesn't want to part' with the bracelet (157). Instead, he resorts to thanking her profusely 'as though it had been a gift offered in love and friendship' (158), but the girl has already turned away: this does not allow Redbourne 'to catch her eye' and 'tell her with a glance or a smile that I had meant no harm' (158), a final exculpatory gesture to reaffirm to himself the anti-conquest nature of the episode.

The reality of white power over aboriginal possessions, the mercantile premises of the transaction, the need for Redbourne to gloss over the event when he includes it in his diary (159), all function in the novel to expose the true conditions of the naturalist's interaction 
with the colony. If the engagement with nature in the outback could result in a potentially salvific ecological understanding of irreconcilable otherness, no such way out is granted to Redbourne's conscience when he is dealing with human beings, the previous inhabitants of that nature, whose relationship with the land before colonisation cannot be encompassed in an ecological discourse of the wilderness that is always already colonial. Not only is the wilderness 'wholly pure by virtue of its independence from humans' (Garrard 78), thus negating the aboriginal presence in - and effect on - the land; 'the wilderness narrative', of which the outback section of this novel is an example, is a Western, metropolitan construct that 'posits a human subject whose most authentic existence is located precisely there' (78). Redbourne's sense of self is indeed crystallised in the outback, but the authenticating of his existence in the wilderness simply confirms a privileged white perspective, which, in true colonial fashion, needs an "other" to validate itself. That the other is natural rather than human makes it easier to ignore the colonial history that enables such encounter with the alien Australian environment in the first place. Thus, although Rifling Paradise questions the conventional trajectory of masculine colonial self-fashioning, it does not fully dismiss its implications, namely, that the empire is a place for self-discovery. In this respect, Poster's novel is consistent with a trend Ann Heilmann identifies in contemporary women writers' deployment of the figure of the naturalist-explorer: while 'the[se] authors interrogate historical conceptualizations of racial and gendered hegemonies and contrast traditionalistimperialist masculine characters with alternative [feminine] figures', they 'do not overturn conventional dichotomies' which equate masculinity with conquest and femininity with nature (92). Neither does Poster use Billy Preece's aboriginal ancestry to provide a viable challenge to either Redbourne's Eurocentric perspective or Eleanor's white-Australian one: by making genetic, instinctive understanding of the land the boy's primary characteristic, the 
novel turns him into an antipodean version of the so-called 'ecological Indian', indigenous people who 'assert their own cultural distinctiveness in the very terms in which they have been idealised' (Clark 122) by environmental discourse and end up becoming complicit in their own reduction to solely natural - rather than rational - beings.

The novel's ending further complicates its espousal of an ecological perspective on the colonial land. On the one hand, Redbourne has been changed by his experiences in the outback, though not in the way he imagined. The specimens he has collected are left behind when he sets out for England, to be replaced by Eleanor, who has become his wife. Given the girl's allegorical function, this resolution provides further commentary on the construction of a vivifying nature in colonial discourse. Thus, Redbourne's masculinity has been reasserted, as indicated by his confirmed heterosexuality, and its manifestation is an authorised appropriation of the land/Eleanor. Her departure from Australia, in turn, is marked by a 'wild and raw' cry, with 'her head thrown back' and her mouth 'drawn at the corners so that the sinews of her neck stood out' (323). She resembles a lorikeet, shot by Bullen and Redbourne early in their acquaintance, whose life is being wrenched from it. Eleanor is leaving behind the land of her birth, to which she is portrayed as having a natural kinship because of the violence visited on both, so that her removal (even as the wife of a now kindly and worthy Redbourne) is an act of violence. The suggestion that her experience is that of an authentic Australian dispossessed of her tie to the soil may be historically accurate, insofar as ' $[\mathrm{t}] \mathrm{he}$ idealistic nationalism' of the colony is founded on 'the pastoral frontier' and therefore on its closeness to the land (Robin 66). However, the substitution of the aboriginal experience for that of a white Australian as the defining national one is left problematically unexplored in the novel. 
On the other hand, whatever understanding about nature Redbourne may have gained during his trip to the outback does not result in a radical refashioning. In fact, he plans to return to England and improve the management of his estate by means of knowledge gained in Australia. While this reverses the epistemological hierarchy between metropolitan centre and colonial outpost, it also confirms Redbourne in the pastoral vision that informed his journey from the start, of 'a plot of fertile land cultivated by my ancestors for more than a century' and continued into 'some future spring' (295-6). The only difference is that he now believes the vision can be put into practice even in the old country. When he entreats Eleanor to forget about her abusive childhood because he is offering her '[a] new life in a new world' (312), the irony of the statement to colonial ears is lost on him.

\section{Unresolved questions}

Rifling Paradise offers a useful corrective to the mainstream treatment of natural history amongst Neo-Victorian scholars as essentially metaphorical or intertextual. By examining the discourse of natural history in a colonial setting, Poster foregrounds the hegemonic pretentions concealed under that science's epistemological claims, while his protagonist shows up the problematic combination of pastoral ideals and literary conventions that cloud the naturalist's ability objectively to recognise the limitations of his knowledge and power. The outback functions as a hostile landscape irreducible to anthropocentric or anthropomorphic readings. As such, it challenges the complex set of discursive and actual practices that underscore natural history's complicity with imperial expansion.

Poster's treatment of landscape is consistent with the particular understanding of ecology Garrard calls 'dwelling', namely, 'the long-term imbrication of humans in a landscape of memory, ancestry and death' (117). In Rifling Paradise the aboriginal past is embedded in the landscape: there are handprints of aboriginals 'everywhere' (198) on the rock 
face near the place where Redbourne and Bullen camp in the outback, accumulating over an undefined timescale and rejecting a clear sense of chronological succession because, as Billy Preece tries to explain to the sceptical naturalists, '[t]hey're here whether we see them or not. The ancestors, I mean. People from the faraway time' (197). Billy's mother leaves her husband and son when she realises she is ill in order to return '[t]o [her] people's lands' (182). Her husband dreams of her 'with the desert stretching as far as you could see on every side' (183), clearly at one with the landscape. These instances suggest that the aboriginals' is the natural (rather than obtrusive) presence because they do not need to domesticate their surroundings.

The handprints are the only material traces of the native inhabitants of Australia (both Billy and the girl with the bracelet being half-caste) and they certainly disrupt scientific discourse. Not only, in fact, do the supernatural occurrences in the outback defy attempts at a rational explanation; the lack of native Australians in the novel means that they are removed from the totalising scope of a scientific discourse that cannot categorise them. However, the latter's replacement with 'dwelling' is problematic. While it values the aboriginal experience as distinct from the conventional Western articulation of the relationship between man and nature (by means of pastoral or wilderness), the very emphasis on the distinctiveness of native Australians perpetuates a colonial understanding that sees them as primitive (albeit with positive connotations to the term) and therefore deprives them of any agency in what is already, by the late nineteenth century and even more in the early twenty-first of the novel's writing, a world steeped in irreversible modernity. Further, although the novel clearly places the moral burden for the fate of Australia on the settlers' shoulders, the crime they perpetrate is against the aboriginals as part of nature, not as individuals whose humanity and singularity is equal to the colonisers' own. The responsibility this entails also grants the colonisers a 
privileged position in the history of the country: in Eleanor, the settlers voice their own guilt and undergo a form of punishment inflicted by their kin. At the centre of the moral drama - as of the scientific, adventurous and exploratory ones that the novel pursues - are still the white Europeans.

\section{Works cited}

Beer, Gillian. Open Fields: Science in Cultural Encounter. Oxford: Oxford University Press, 1996

Beinart, William and Lottie Hughes. Environment and Empire. Oxford History of the British Empire: Companion Series. Oxford: Oxford University Press, 2007

Buell, Lawrence. The Environmental Imagination: Thoreau, Nature Writing and the Formation of American Culture. Princeton: Princeton University Press, 1995

Byatt, A.S. On Histories and Stories: Selected Essays. London: Chatto \& Windus, 2000

Clark, Tim. The Cambridge Introduction to Literature and the Environment. Cambridge: Cambridge University Press, 2011

Dixon, Robert. Writing the Colonial Adventure: Race, gender and nation in Anglo-Australian popular fiction, 1875-1914. Cambridge: Cambridge University Press, 1995

Drayson, Nicholas. Confessing a Murder. London: Vintage, 2002

Garrard, Greg. Ecocriticism. New Critical Idiom. Abingdon: Routledge, 2012

Griffiths, Tom. 'Ecology and Empire: Towards an Australian history of the world.' Ecology and Empire: Environmental History of Settler Societies. Ed. Tom Griffiths and Libby Robin. Edinburgh: Keele University Press, 1997. 63-75

Heilmann, Ann. 'Neo-Victorian Darwin: Representations of the Nineteenth-Century Scientist, Naturalist and Explorer in Twenty-First-Century Women's Writing.' Reflecting on Darwin. Ed. Eckart Voigts et al. Farnham: Ashgate, 2014. 91-111

Ho, Elizabeth. Neo-Victorianism and the Memory of Empire. London: Bloomsbury, 2012

Hooper, Glenn. Landscape and Empire: 1770-2000. Aldershot: Ashgate, 2005

Kohlke, Marie-Louise and Christian Gutleben. 'Introduction.' Neo-Victorian Tropes of Trauma: The Politics of Bearing After-Witness to Nineteenth-Century Suffering. Amsterdam: Rodopi, 2010. 1-34

King, Rachel. The Sound of Butterflies. Auckland: Black Swan, 2006

Kneale, Matthew. English Passengers. London: Penguin, 2000 
Lang, Andrew. 'Realism and Romance.' Contemporary Review 52 (November 1887): 683-93

Letissier, Georges. 'Trauma by Proxy in the "Age of Testimony": Paradoxes of Darwinism in the Neo-Victorian Novel.' Kohlke, Marie-Louise and Christian Gutleben. 73-98

McDonald, Roger. Mr Darwin's Shooter. London: Penguin, 1998

Pesso-Miquel, Catherine. 'Apes and Grandfathers: Traumas of Apostasy and Exclusion in John Fowles's The French Lieutenant's Woman and Graham Swift's Ever After.' Kohlke, Marie-Louise and Christian Gutleben. 99-132

Poster, Jem. Rifling Paradise. London: Sceptre, 2006

Pratt, Mary Louise. Imperial Eyes: Travel Writing and Transculturation. London: Routledge, 1992

Robbins, Ruth. Pater to Forster, 1873-1924. Basingstoke: Palgrave Macmillan 2003

Robin, Libby. 'Ecology: A Science of Empire?' Ecology and Empire: Environmental History of Settler Societies. Ed. Tom Griffiths and Libby Robin. Edinburgh: Keele University Press, 1997. 63-75

Scholz, Susanne and Nicola Dropmann. 'The Props of Masculinity in Late Victorian Adventure Fiction.' Constructions of Masculinity in British Literature from the Middle Ages to the Present. Ed. Stefan Horlacher. Basingstoke: Palgrave Macmillan, 2011. 169186

Shuttleworth, Sally. 'Natural History: The Retro-Victorian Novel.' Shaffer, Elinor S., ed. The Third Culture: Literature and Science. Berlin: de Gruyter, 1998. 253-268

Thompson, Harry. This Thing of Darkness. London: Headline, 2006

White, Andrea. Joseph Conrad and the Adventure Tradition: Constructing and Deconstructing the Imperial Subject. Cambridge: Cambridge University Press, 1993

Woollacott, Angela. Gender and Empire. Basingstoke: Palgrave Macmillan, 2006 